\title{
The Role of Information Technologies in Micro Destination Marketing: An Application in 4-5 Star Hotels
}

\author{
Mikro destinasyon pazarlamasında bilgi teknolojilerinin rolü: 4-5 yıldızlı \\ otellerde bir uygulama
}

Osman ÜNÜVAR ${ }^{1}$

Mete SEZGIN 2a

Mürsel KAYA ${ }^{3}$

\begin{abstract}
${ }^{1}$ Necmettin Erbakan University, Seydişehir Vocational School, Konya. osmanunuvar@konya.edu.tr ${ }^{2}$ Selçuk University, Faculty of Tourism, Konya. metesezgin@selcuk.edu.tr

${ }^{3}$ Selçuk University, Silifke Taşucu Vocational School, Konya. murselkaya@selcuk.edu.tr a Yazıșılan yazar/Corresponding author
\end{abstract}

\begin{abstract}
The rapid development of IT (Information Technologies) in today's world has caused the effects of globalization to radically change the perceptions in the tourism sector. From the 80's until today, Turkey has covered a very important distance in the field of tourism. At this time of period, the traditional structure of tourism has undergone a complete change and the necessity of information technology has been understood and the sector has redesigned itself in the context of technology. Turkey as a destination is a tourism country with different tourism advantages. Factors such as being the biggest open air museum in the world, being hosted by many civilizations, being in the Mediterranean climate zone, geopolitical position, diversity of tourism investments, diversity of tourism, and educated human power are the main features that make Turkey attractive in the sense of destination. As a micro-destination, Konya has become a destination which is subject to curiosity of both domestic and foreign tourists, and has rises in the world day by day about both health tourism and faith tourism. With an integrative approach, information technology is crucial for the tourism sector and issues such as the simplification of the sector in terms of workload, to what extend it affects the productivity of tourism enterprises in a positive way; the transparency of information and how well it manages the information will be addressed in this study.
\end{abstract}

Keywords: Tourism, Micro-Destination, Information Technologies, Tourism Marketing

JEL codes: D00, D80, O14.

doi: $10.5505 /$ pjess.2017.92400

\section{Özet}

Günümüz Dünya'sında bilgi teknolojinin, baş döndüren bir hızla gelişmesi, küreselleşmenin etkileri, turizm sektöründeki anlayışların kökten değişmesine neden olmuştur. Türkiye'de turizm alaninda 80'li yıllardan günümüze kadar çok önemli bir mesafe kaydedilmiştir. Bu zaman diliminde turizm alanindaki geleneksel yap tümüyle değişime uğrayarak bilgi teknolojilerin gerekliliği anlaşılarak, sektör kendini teknoloji bağlaminda yeniden dizayn etmiştir. Türkiye destinasyon olarak farkl turizm avantajlarna sahip bir turizm ülkesidir. Dünya'nın en büyük açık hava müzesi oluşu, birçok medeniyete ev sahipliği yapmış olması, Akdeniz iklim kuşă̆ında olması, jeopolitik konumu, turizm yatırımlarm çeşitliği, turizm çeşitliliği, yetişmiş insan gücü, turizm bölgelerindeki yerel halkın turizmi benimsemiş olmaları gibi faktörler Türkiye'yi destinasyon anlamında çekici kulan temel özelliklerdir. Mikro destinasyon olarak Konya, hem sağlik turizminde, hem inanç turizminde gün geçtikçe yıldızı parlayan yerli ve yabancl turistler tarafindan merak edilen bir destinasyon haline gelmiştir. Bütüncül yaklaşımla bilgi teknolojileri turizm sektörü için son derece önemli ve sektörü iş yükü anlamında basitleştirmesi, turizm işletmelerinin verimliliğini hangi ölçüde olumlu yönde etkilediği, şeffaf oluşu ve bilgiyi ne derece ve nasıl yönettiği gibi konular bu çalışmamızda ele alınacaktır.

Anahtar kelimeler: Turizm, Mikro Destinasyon, Bilgi Teknolojileri, Turizm Pazarlaması

JEL kodlart: D00, D80, 014 


\section{DESTINATION}

\subsection{Definition of Destination}

The origin of the concept of tourism constitutes the word of tornus that expresses the rotational movement in Latin. The words touring and tour in English are also derived from this word (Ünlüönen et al., 2007: 16; Öztürk and Bayat, 2011: 138).

Tourism is a relatively important field of action, and tourism is the emergence of economic, social and physical influences. Tourism is a destination of countries, regions and cities in which there are the basic economic activities of tourism (www.kultur.gov.tr).

The word "destination", which originated from French language to our language, is defined as "the place to be reached" in the Dictionary of Turkish Language Institution (www.tdk.gov.tr).

The destination is primarily considered as a system where inputs and outputs, society, services and business areas are involved. Hence, a vital component of this system is the framework that connects the members of the system, in other words, the people and the places at the destination level. A destination is composed of a whole integrated structure consisting of tourism attractiveness, tourism enterprises, local people and local government (Özdemir, 2008; cited in Kocaman, 2012: 10).

A destination can be defined as a geographical location that has various tourist attractions and features, and can offer some or all of the touristic products that satisfy the tourists' needs during the trip (Ülker, 2010: 7).

The World Tourism Organization (WTO) defines a local tourism destination as: a physical place where a visitor spent at least one night. It includes tourism products such as support services and attractiveness and tourism resources in a day's travel. A destination has the physical and managerial limits that define administration; and also images and perceptions that define competitiveness in the market. It combines various stakeholders, often including host communities, and can gather and network to create wider destinations. A destination can be defined as a country, a region, a city, or a place in which touristic products such as tourist attractions, tourist attractions, natural attractions, historical elements, festivals, events, eating and drinking opportunities, infrastructure characteristics of the region are presented and offered to visitors (Ülker, 2010, s.8). Tourism destination is also defined as a geographical location or region in which the tourist community is in the local community. The destination is primarily considered as a system in which inputs and outputs, society, services and work spaces are involved. A destination has a complex structure consisting of tourism attractions, tourism enterprises, local people and local government. However, a destination, due to this complex structure, is a relatively difficult tourism concept to manage (Kocaman, 2012: 11).

The meaning attached to the concept of destination may vary depending on the definition of the region. When the features selected to define the destination are related to the dimensions of tourism development, the regions analyzed can be called tourism destinations.

A wide definition of a tourism destination is a branded national area with a certain image in the human brain, larger than quite many cities in the country and smaller than whole 
country, and a geographical area sufficient for the development of tourist facilities. It has a good transportation network established in the region with various tourist attractions, attraction centers, festivals, carnivals, potential of development, interregional and countrylevel transport facilities connected to the internal transport network (Ersun and Arslan, 2011: 231).

A tourist destination can be defined as a system having a series of elements such as attractions, accommodation, transportation, infrastructure and other services, or as a continent that attracts visitors for temporary accommodation, states, provinces, cities, counties or resorts built for this purpose (Güçer et al., 2013: 49).

\subsection{Destination Properties}

1. There are a wide variety of destinations, and destinations have some common features such as being touristy and being preferred by tourists. These features are:

Destinations are an integral part from the view point of attractiveness. They are made up of 4 characteristic titles, even if they are of different content due to cultural, economic and environmental reasons.

-Destinations are attractive.

-They have infrastructure and superstructure facilities (accommodation, food, beverage, entertainment).

-They are reachable (Local transport, transport terminals).

-They have supporting services (Local organization services).

2. Destinations are a cultural asset; Tourist destinations should be seen as an attraction worth visiting. Good design, good management and marketing, the belief that the destination is unique, provide the continuity of the supply for this destination.

3. Destinations are consumed where they are produced. Tourism is inherently attractive, unique and fragile. Destinations are sensitive to the actions of tourists and are influenced by their behavior. Also, destinations like all services can be deteriorated and disappear if not used well.

4. Destinations are not only used by tourists but also by other groups. The destination offers residence and services throughout the year, but there are local residents, day trippers and tourists who temporarily make use of the destinations at different times of the year (Kurt, 2009: 10).

\subsection{The Image of the Destination}

The destination image is a key concept in the choice of the resort (Colton, 1987; Hunt, 1975; Telisman-Kosuta, 1989). Baloglu and Bringberg (1997) state that image is a phenomenon making destinations different from each other, and that tourists affect the decision process. Therefore, it is primarily important to examine the factors that can be influenced by (probable) tourists who have not yet chosen a holiday place, and to show how these elements are effective on marketing the destination (Yaraşl1, 2007: 7). 


\section{TOURISM MARKETING}

Tourism Marketing is consists of national tourism organizations or tourism enterprises having systematic and coherent efforts to optimize the satisfaction of the needs of tourists at national and international levels. People's desire to travel in a region or a country for the purposes of business, family, meeting in order to evaluate their leisure time has led to the emergence of touristic enterprises. These enterprises have been developing a range of methods and techniques aimed at making the most suitable the holiday in the best financial conditions for the tourist groups of consumers (birgo.mynet.com).

\subsection{Benefits throughout Tourism Marketing}

When we look at tourism marketing in terms of individual tourism, the goods and services produced by each tourism operation are expressed as touristic products. Services such as food and beverage, leisure sports, shopping, swimming pools, car rentals offered by the accommodation companies constitute a separate part of the tourist product. Tourism enterprises also serve consumers in a wide variety of forms and with different products. In the tourism sector, the benefits of tourism marketing have an important place. Especially, it can be said that the components brought together with the package tour provide important benefits to each share holders in the sector. However, these benefits cannot be determined separately. However, it is known that the created package tour has contributed significantly to the participation of prospective consumers in tourism events. Nowadays, traditional competition tools can be added to various factors. One of them is the benefits of tourism marketing (Akkılıç, 2003: 214-215).

\subsection{Distribution Channels in Tourism Marketing}

The distribution channel in tourism is a structure formed by in-house units or non-business marketing organizations making efforts to deliver products and the right to use tourist products to consumers. The World Tourism Organization (WTO) has defined the distribution channel in tourism as "a combination of intermediaries working in the sale of a tourist product". Distribution channels are increasingly regarded as one of the most important factors in marketing as they express the competitiveness and profitability of organizations. The position of the distribution sector in tourism is much stronger: travel agencies, tour operators, charter agents, reservation systems and other travel distribution specialists are much more sophisticated than their counterparts in other industries in influencing and directing tourism. Due to the fact that they can keep the demand under control, they have increased their bargaining power the producers of the tourism services, so they can easily influence the producers' activities for pricing, production and promotion (eprints.sdu.edu.tr).

\subsection{Consumer (Tourist) Behavior in Tourism Marketing}

Tourism has a characteristic of creating a social event, a means of psychological satisfaction, an area of economic activity, a cultural activity and many other activities on the field. The technological and economic developments in the world, the increase in the amount of income per capita, the monotonous life style and the concentration of natural beauties at certain points, rapid urbanization and noise cause people to participate in tourism activities. Communication and transportation tools developing with technology conformably contribute to the development of tourism and the people to travel a lot (Hayta, 2008: 39). 


\section{INFORMATION TECHNOLOGIES (IT)}

\subsection{Tourism Industry and Information Technologies}

Technological developments have made important changes in the tourism sector as well as in other ones. The possibilities provided by information technology have created significant opportunities for consumers and service providers in this sector, and have provided important opportunities for competitiveness in businesses.

\subsection{Importance of Information Technologies for Tourism Enterprises}

When we look at the rates of information technology utilization in the tourism sector in the world, it is estimated that $10 \%$ of Internet users use it for transactions such as internet, shopping, banking, travel. According to the statistics of Travel Web, $14 \%$ of those who make hotel reservations via the Internet are senior managers, 33\% are between the ages of 31-40, and $75 \%$ of those making bookings are American (Peilt, 2009: 14-16). E-commerce is one of the fastest growing segments. Improvements in search engines, transport capacity, speed in the networks and number of passengers have also affected tourism plans and revenues profoundly (García-Crespo et al., 2011: 13311). Using this information, which is very easy to reach, they can focus on the full development of a tourist center in a sustainable way. The use of technology for sustainable tourism can provide a link between the visitor and the tourism industry in structuring the platforms in which the public, tourist enterprises and tourists share the same interests, and can provide information on sustainable beneficial tourism issues. This not only increases tourist satisfaction, but also constitutes a method of training all parties. This increases the coordination and participation of the various stakeholders in the field of sustainable tourism and in supporting relations (Ali and Frew, 2014: 59-70). Information Technologies provide competitiveness and significant competitive advantage to tourism enterprises as an important contribution. The restructuring of the existing tourism industry will provide the creation of a new tourism industry, and start a new way of the competition of radical change firms and tourism regions. Information technologies enable competition in economic activities for tourism enterprises, and new formations that create value for consumers and suppliers. For this reason, organizations adapting information technologies to their tourism businesses can have a competitive service structure. As a result, while businesses placing information technologies in their enterprises on time provide sustainable competitive advantage, it is also seen that they have increased their profit margins over the years (Buhalis, 1998: 410). To improve the use of information in the tourism sector and to provide information flow, information system allowing only automatic dissemination of information, and information gathered and processed information (e.g. for universities, environmental organizations, non-governmental organizations), feedback loop and implementation (e.g. for tourism enterprises, planners, developers, tourists) is an essential foundation for incentives and a key resource for the tourism sector and an essential process for the continual learning cycle. The starting points for the development and implementation seem to be extremely important within target marketing information systems of the tourism sector (Schianetza et al., 2007: 1488-1489). The Internet and tourism relationship aims to detect the perceptions of tourists and the factors and instrumentation, travel situations and tasks for their selection, to prove different interaction possibilities through the WebGIS system (Chang and Caneday, 2011: 1435). The 
popularity of 3D GIS solutions for desktop computers is rapidly growing among users and is considered a very important development for the tourism sector.

\section{IMPLEMENTATION}

\subsection{Purpose of the research}

The share of tourism sector in all income items, and its importance are extremely important for the Turkish economy. It is possible that this share in economic activities can be continuously increased. Micro-destination marketing is one of the most important items of the tourism sector and it is also important to be able to introduce micro destinations properly, to increase tourism incomes and to obtain sustainable competitive advantage among destinations. Considering the contributions of the IT made to tourism sector, it brings with it many advantages such as revealing the attractiveness of the destinations and the efficiency of the tourism enterprises, and marketing at the global scale. The study aims to determine the level of use or the wish of using IT by tourism businesses. Discovery of information from large databases is very important. Rule-based presentation and intelligibility of information, in particular, improves interpretability considerably (Uzun et al., 2016: 5452). This is a study aiming to show the integration and usage the level of IT of 4 and 5 stars hotels in Konya, which has an important place in the context of micro-destination marketing, and the contribution of the accommodation companies to the destination marketing.

\subsection{Method}

The method of special case study is used in the study. The special case study will focus on a specific case and allows very fine details to be explained in terms of mutual relations of cause and effect and variables (Kanbolat et al., 2012: 161).

\subsection{Data Collection Tools}

The data used in the study were collected by semi-structured interview questions prepared by the researcher. These questions were developed from the scale used by Benli (2002: 3). The semi-structured interview form was prepared by referring to the expert opinion.

\subsection{Data Collection and Analysis}

The interviews were conducted with the managers of the hotel and the managers of the various departments at 3 hotels with 5 stars and 8 hotels with 4 stars (totally 11 hotels) operating in Konya city center between December 2015 and January 2017. Negotiations were recorded on semi-structured interview forms prepared for each hotel separately. The interviews lasted 15-20 minutes and 7 pre-determined questions were asked and answered. The interviews were then assessed and the data was analyzed. The data obtained from the interviews were interpreted by giving codes and giving definitions. In the analysis of the data and in the interpretation of the findings, the necessity of creating the tables was taken into consideration by taking into consideration the sub-problems of the research and the tables created were interpreted properly. 


\subsection{Findings}

Table 1. General information about the hotel

\begin{tabular}{lcc}
\hline Star & rooms (min-max) & staff (min-max) \\
\hline 8 hotels with 4 stars & $80-228$ & $30-92$ \\
3 hotels with 5 stars & $183-278$ & $150-200$ \\
\hline
\end{tabular}

There are 11 hotels with 4-5 stars in Konya and the number of rooms and personnel in these rooms are seen in table 2. There are a total of 1561 rooms and a total of 4737 personnel in 4-5 stars hotels in Konya.

Examples of the answers given by the hotel managers in the question "Do you think there is a relationship between IT usage requirement, frequency and variety?", and the codes and frequencies generated from these answers are given in Table 3.

Table 2. Hotel Managers' Perspectives on Information Technologies

\begin{tabular}{|c|c|l|}
\hline Codes & Frequency & Examples from Hotel Management's Opinions \\
\hline Partly & 3 & $\begin{array}{l}{[\ldots] \text { Information technology is not required in all processes in hotel }} \\
\text { operations but is necessary for certain jobs [...] }\end{array}$ \\
\hline Completely & 8 & $\begin{array}{l}{[\ldots] \text { Information technology is an indispensable requirement for today's }} \\
\text { hotel business [...] }\end{array}$ \\
\hline
\end{tabular}

When Table 2 is examined, it can be seen that some of the hotel managers do not need information technologies in all processes in hotel operations, but are required in certain jobs and in certain departments; the vast majority of them point out that information technology is a very important requirement for hotel management. In this context, the opinion of the manager with the code of O-3 is very important: [...] Information technology is now the reason for the existence of hotel enterprises today. If you use, you are there, if you do not use, you do not exist (O-3)

Examples of the answers given by Hotel Managers to the question "What are the reasons for Hotel Enterprises to use the Internet?" and the codes and frequencies generated from these answers are given in Table 3.

Table 3. Opinions of Hotel Managers about Reasons for Using the Internet

\begin{tabular}{|c|c|l|}
\hline Codes & Frequency & Examples from Hotel Management's Opinions \\
\hline Follow the reservation & 7 & $\begin{array}{l}\text { To follow all kinds of information about reservations. } \\
\text { How many people, when, how many days, payment etc. }\end{array}$ \\
\hline Communication & 2 & Communication with agencies and suppliers. \\
\hline Mail & 2 & To send an e-mail to the hotel's surroundings. \\
\hline
\end{tabular}

When Table 3 is examined, some of the hotel managers have reported that they use the internet only in order to follow the reservation. The other managing staff stated that they consider the internet only as tool of communication while the remaining part regards them as a mail tool. The opinions of the participant coded $(\mathrm{O}-4)$ on the reasons why hotel managers use the internet are as follows: Despite the fact that the Internet is a technology 
that is necessary in all business processes, they have used the expression of "window open" to the world from attracting customers to supplying the sales force in the enterprises that perform the service delivery.

Examples of the answers given by Hotel Managers to the question "Do you have a website?", the codes and frequencies generated from these answers are as in Table 4.

Table 4. Opinions of Hotel Administrators about Their Web Site.

\begin{tabular}{|c|c|l|}
\hline Codes & Frequency & Examples from Hotel Management's Opinions \\
\hline Yes & 10 & $\begin{array}{l}\text { In today's tourism businesses, they have expressed the website is both a } \\
\text { very important and legal necessity }\end{array}$ \\
\hline No & 1 & $\begin{array}{l}\text { They express that it is important to have the website for hotel management, } \\
\text { but their hotel doesn't have its own private website; they use the website of } \\
\text { group hotels instead. }\end{array}$ \\
\hline
\end{tabular}

When we look at Table 4, almost all of the hotel managers expressed that the web site is the necessity and legal obligation for the hotel management. Only one executive group stated that they use the same website with their group hotels. The manager coded (O-1) also says that web sites are a tool by the help of which 'far' becomes 'near for the future guests and which makes the facilities familiar with them in advance.

The manger coded (0-6) states that they try to keep their website up-to-date by redesigning their web sites according to their day-to-day experience, which has got a positive effect on local, regional and national sales.

Examples of the answers given by the Hotel Administrators for the question "What is the software state used?" and the codes and frequencies generated from these answers are as in Table 5.

Table 5. Opinions of Hotel Administrators about the Software Status Used

\begin{tabular}{|l|c|l|}
\hline \multicolumn{1}{|c|}{ Codes } & Frequency & Examples from Hotel Management's Opinions \\
\hline Front office software & 1 & $\begin{array}{l}{[\ldots] \text { Front desk software is the place where the first }} \\
\text { data entry for hotel management takes place [...] }\end{array}$ \\
\hline Back office software & 4 & $\begin{array}{l}{[\ldots] \text { the more up to date back office software, the better }} \\
\text { to transfer information to other departments [...] }\end{array}$ \\
\hline Back office software & 5 & $\begin{array}{l}\text { Existing software meets the need of the hotel according } \\
\text { to the size of the hotel business. }\end{array}$ \\
\hline Front office-office software & 1 & $\begin{array}{l}{[\ldots] \text { the software is used to the extent required by all }} \\
\text { hotel business [...] }\end{array}$ \\
\hline
\end{tabular}

When reviewing Table 5, the hotel managers think that the front desk software used is the unit of data entry for hotel management. Some managers state that the front office software must always be up to date for a hotel management to transfer the information to other departments properly. The other managers think that the existing software meets the needs of the operator according to the size of the hotel enterprises. Only 1 participant uses office software in all his hotel businesses. The opinion of the participant with code (O-5) about the software status of hotel managers is remarkable. There is a lot of software used by hotel 
operators (opera, elektra, fidelio etc.). Hotel management should decide very seriously which program will be suitable for the business flow of the business, because a wrong decision of program selection will adversely affect the flow of business for all businesses.

Examples of the answers given by the Hotel Administrators for the question "Their Priorities for Purchasing Automated System Preference?" and the codes and frequencies generated from these answers are as in Table 6.

Table 6. The views of the hotel managers' priorities on Purchase System Preferences

\begin{tabular}{|l|c|l|}
\hline Codes & Frequency & Examples from Hotel Management's Opinions \\
\hline Advice and references & 2 & Suggestions from other users in the industry. \\
\hline Being the cheapest system & 4 & $\begin{array}{l}\text { Being in reasonable price range, doing the same } \\
\text { average jobs with other expensive systems. }\end{array}$ \\
\hline Being the best quality system & 2 & $\begin{array}{l}\text { Having good quality, different features than other } \\
\text { systems. }\end{array}$ \\
\hline Ads & 1 & The programmer's advertisements are determiner. \\
\hline Support after sale & 1 & They think we will get support and service after sales \\
\hline Brand reason & 1 & The brand element is determiner. \\
\hline
\end{tabular}

When Table 6 is examined, it is seen that the preference of the half of the hotel managers is to purchase the cheapest and the best quality system. A small part of the other managers pointed out that the advertisement of the software company, the belief of receiving proper support and services after sales to be taken, and the other decisive factor is the brand element in the software for the hotel managers. The views of the manager coded (O-7) are very striking in the priorities in which the hotel managers prefer the system to buy. They argue that every business in the hotel management is closely related to the system, you can update the system, but changing the system in a very short period will bring some dissatisfaction.

Examples of the answers given by the Hotel Administrators for the question "Request to Change System?" and the codes and frequencies generated from these answers are as in Table 7.

Table 7. Opinions about question of "the request of the Hotel Administrators to Change the System"

\begin{tabular}{|l|c|l|}
\hline Codes & Frequency & Examples from Hotel Management's Opinions \\
\hline Yes & 0 & {$[\ldots]$ the staff adaptation problems will arise $[\ldots]$} \\
\hline No & 10 & We certainly do not want to change. \\
\hline No answer & 1 & The manager did not want to answer. \\
\hline
\end{tabular}

When Table 7 is examined, all hotel managers state that they are not in the request to change the system. The main reason for this situation is that the adaptability of the staff to the new system reveals new problems. A manager has not responded to the the question of the request to change the system. The answer of the manager coded $(\mathrm{O}-8)$ for the question of 
"Are you willing to change the system?" is very important. To him, the desire to change the system at a city hotel in a destination like Konya means that you will not be able to reach your goals and it will prevent you from doing the work you need to do. The manager coded (O-9) states that Konya has gone a long way in the tourism field; in addition to the fact that there are important developments in the area of belief and health tourism, there are 3 private organized industrial zones, 4 universities, 3 regular military exercises by the Main Jet Base Command within NATO partnership in Konya adding that it is unnecessary to change the system in a accommodation enterprise operating tourism activities in 4 seasons.

Examples of the answers given by the Hotel Administrators for the question "Expectations from the Information Sector?" and the codes and frequencies generated from these answers are as in Table 8.

Table 8. Opinions about question of "Hotel Managers' Expectations from Information Technologies"

\begin{tabular}{|l|c|l|}
\hline Codes & Frequency & Examples from Hotel Management's Opinions \\
\hline Let them manufacture software & 2 & $\begin{array}{l}{[\ldots] \text { Solutions for hotel management's work }} \\
\text { and hardware making things easier }[\ldots]\end{array}$ \\
\hline $\begin{array}{l}\text { Products and services are } \\
\text { expensive; We hope them to } \\
\text { cheapen them }\end{array}$ & 2 & {$[\ldots]$ Technology is expensive $[\ldots]$} \\
\hline $\begin{array}{l}\text { Let them report us the } \\
\text { innovations related to tourism }\end{array}$ & 2 & New solutions about the industry. \\
\hline $\begin{array}{l}\text { Let them give education and } \\
\text { support after sale }\end{array}$ & 2 & $\begin{array}{l}{[\ldots] \text { They should have the skill of solving }} \\
\text { problem[...] }\end{array}$ \\
\hline $\begin{array}{l}\text { Let them promote themselves } \\
\text { well }\end{array}$ & 3 & $\begin{array}{l}\text { The specialities of their technology must be } \\
\text { promoted well }\end{array}$ \\
\hline
\end{tabular}

When Table 8 is examined, it can be summarized: hotel managers' expectation from information technology is that it should offer hardware and software to facilitate their business, providing facilitating solutions to the hotel management. And also; it is important that the products and services are very expensive, the managers have the desire of cheapening products and service, and searching for innovations related to the tourism sector, and offering innovations related to the tourism sector and engaging the innovations to the industry very fast. Hotel managers have said that after-sales training support services, aftersales services should be provided in a higher quality due to lack of technology or very difficult. They have also said that technology producers should be better able to promote themselves, and in this context, tourism package programs and equipment producers should respond more quickly to the needs of the industry. The opinion of the manager coded (O-9) on the expectations of information technology is as follow: Information technology is very important in the tourism sector as in every sector. Because the tourism sector is a serviceoriented sector, the need for information technology is greater than in other sectors, in which tourism collaborators should be able to respond to the industry needs of program and equipment quickly and with a solution-oriented approach. The opinions of the manager coded (O-10) are also very striking. That manager talks about the necessity of establishing a 
government incentive system in order to design information technology so that the tourism industry can compete in the global market.

Unstructured subjects and issues in the interviews apart from the questions above are these:

Inadequacy of Qualified Staff: Hotel managers express that they operationally meet the necessity of personnel they need in certain times but they express the fact that they face the inadequacy of finding qualified man power for the tourism sector in Konya.

Cost of programs: The cost of installing up the lowest hotel program system on the average market starts from $\$ 10,000$ and may rise up $\$ 60,000$. The mangers have pointed out that the cost of hotel automation programs have increased much due to the advantages such as effective program management, facilitating sales, overcoming language barriers, and implementing effective price management.

Demand fluctuation on some special days and times: Individuals and group customers such as agency customers and businessmen seem to prefer hotels in changing charts. For example, the changing profile and fluctuations are seen at Mevlana ceremonies, New Year, holiday days, weekdays and weekends. In this respect, IT has a big significance. Promotion and marketing activities carried out by using transportation, the principles of pull and push to these customers in the data portfolio matter so much.

Integration problem with other accommodation and tourism establishments in Konya: The affluence and the structural distribution of tourism enterprises in Konya city hotels do not cause any problems but rather they provide a competitive advantage. However, the fact that there is no integrated IT that provides tourism related links such as airports, airplanes, high-speed trains, A group travel agencies, souvenir shops, museums, etc., which makes the concept of "one hotel alone cannot do business" dominant in tourism.

\section{RESULT}

The destination is a country, region, city or place that has tourist attractions such as natural beauty, historical and cultural features, festivals, events, eating and drinking facilities for the visitors, infrastructure characteristics of the region in order to evaluate the leisure time of the people participating in the tourism. Destination means "a place to arrive at/in". The concept of destination depending on the technological developments confronts us as the competition, advantages and services in accommodation, food \& beverage and travel sectors. The microdestination shows the big frame and how to focus on one point of the photo. For example, while Turkey is a general destination; Cappadocia, Belek, Pamukkale, Konya, etc. are described as micro-destinations. Even when the concept is evaluated on the basis of hospitality, the area is getting narrower.

Destination marketing is the process of making a destination identity that is tailored to the core product of a place to become a center of attraction with effective marketing communication efforts towards selected target tourists and to sell the area. Destination marketing is a building and supporting stone of the development of a specific place, and it especially contributes to regional development and development.

As for IT, while providing a wide range of opportunities in terms of destination marketing, it is particularly important in terms of obtaining and storing data, and serving the tourists in 
the hospitality sector. This internally provided data also is used to carry out different applications such as advertising and promotion towards to the present, target and potential customers.

For example; if a destination does not exist on the web, it means that destination cannot reach millions of people entering the internet. It is necessary to use and manage such a potential powerful internet in the most effective way. In this case, the accuracy and quality of the information presented on the internet is considered to be the most powerful weapon of that destination. In other words, IT faces us as an effective method of marketing the destination.

In this research, the role of information technology in micro-destination marketing has been tried to be investigated. Today IT has become an indispensable part of not only tourism enterprises but also many companies, institutions and businesses.

In the survey, interviews were held with the hotel managers and the managers of various departments of 11 hotels, 3 of which are 5 star and 8 of which are 4 star hotels operating in Konya city center. The research is based on the case study method. The special case study can explain very fine details, reasons-results and variables in terms of correspondence relations by focusing on a specific case. The data used in the study were collected by semistructured interview questions prepared by the researcher. For this purpose, this study aims to determine the level of using IT of 4 and 5 star accommodation companies and contribution with destination marketing and integration with the tourism industry in Konya, which has an important place in the context of micro-destination marketing.

In summary, some of the managers in Konya claim that IT are not necessary in all processes in hotel enterprises but they are needed in some certain jobs and departments; the vast majority of them point out that information technology is a very important requirement for hotel management.

Some of the hotel managers reported that they only use the internet to follow-up the reservation. Internet in hotels is used at the level of $100 \%$. Today, using a website is both a very important requirement and a legal necessity statement.

Opinions of hotel managers about the software status in use: front office software is the unit of data entry for hotel management; some managers said that the information transfer for other departments can be healthy only if the front office software is up to date. More than half of hotel executives have priorities on their own preference for purchasing a system and first of them is being the cheapest system and the best quality system. All hotel managers state that they are not willing to change the system. The expectation of hotel executives can be summarized from information technology is that hardware and software facilitating their business must be produced and must provide facilitating solutions to hotel management. 


\section{REFERENCES}

Akkılıç, M. E. (2003). Turizm Pazarlamasında Faydalar ve Bir Turist Tatmin Modeli Önerisi. Fırat Üniversitesi Sosyal Bilimler Dergisi, 13(2), 211-232.

Ali, A., \& Frew, A. J. (2014). Information Communication Technologies and Sustainable Tourism. New York, NY, USA: Routledge.

García-Crespo, Á., Luis López-Cuadrado, J., Colomo-Palacios, R., González-Carrasco, I., \& Ruiz-Mezcua, B. (2011). Sem-Fit: A Semantic Based Expert System to Provide Recommendations in the Tourism Domain. Expert Systems with Applications, 38(10) 13310-13319.

Benli, T. ve Kızgın, Y. (2002). Konaklama İşletmelerinde Bilgi Teknolojisi Kullanımının Önemi Üzerine Bir Alan Çalışması: Muğla İli Örneği. Mevzuat Dergisi, 5(52), 3-15.

Buhalis, D. (1998). Strategic Use of Information Technologies in the Tourism Industry. Tourism Management, 19(5), 409-421.

Ersun, E. ve Arslan, K. (2011). Turizmde Destinasyon Seçimini Etkileyen Temel Unsurlar ve Pazarlama Stratejileri. Marmara Üniversitesi İ.I.B.F. Dergisi, 31(2), 229-248.

Chang, G., \& Caneday, L. (2011). Web-Based Gis in Tourism Information Search: Perceptions, Tasks, and Trip Attributes. Tourism Management, 32(6), 1435-1437.

Güçer, E., Hassan, A. ve Pelit, E. (2013). Destinasyon Pazarlamasında Belediye Web Sayfalarının Önemi: Türkiye'deki Büyükşehir Belediyelerinde Bir İnceleme. Manas Sosyal Araştırmalar Dergisi, 2(4), 47-62.

Hayta, A. B. (2008). Turizm Pazarlamasında Tüketici Satın Alma Süreci ve Karşılaşılan Sorunlar. Kastamonu Eğitim Dergisi, 16(1), 31-48.

http://birgo.mynet.com/niyazigumus/yazi/turizm-pazarlama (Date Accessed: 19.11.2014).

http://eprints.sdu.edu.tr/33/1/TS00205.pdf. (Date Accessed: 19.11.2014).

http://www.kultur.gov.tr/TR,31239/turizm-destinasyonu-nedir.html (Date Accessed: 09.11.2014).

http://www.tdk.gov.tr (Date Accessed: 09.11.2014).

Noguera, J. M., Barranco, M. J., Segura, R.J., \& Martínez, L. (2012). A Mobile 3d-Gis Hybrid Recommender System for Tourism. Information Sciences, 215 (2012), 37-52.

Kanbolat, O., Altunbaş, S. ve Çakmak, Z. (2012). Araştırma Görevlilerinin Bilimsel Makaleler Hakkındaki Görüşleri. Eğitim ve Öğretim Araştırmaları Dergisi, 1(4), 160-169.

Schianetza, K., Kavanaghb L., \& Lockington, D. (2007). The Learning Tourism Destination: The Potential of a Learning Organisation Approach for Improving the Sustainability of Tourism Destinations. Tourism Management, 28(6)1485-1496

Kocaman, S. (2012). Destinasyon Yönetimi Kapsamında Marka Kimliğine Etki Eden Faktörlerin Marka İmajına Etkisi: Alanya Örneği. Akdeniz Üniversitesi, Sosyal Bilimler Enstitüsü, Turizm İşletmeciliği Ve Otelcilik Anabilim Dalı, Yayınlanmamış Doktora Tezi, Antalya. 
Kurt, S. (2009). Kültür ve Turizm Bakanlı̆̆ı, Turizm Yönetimi ve Pazarlama Stratejileri. Çalışma Raporu.

Öztürk, M. ve Bayat, M. (2011). Uluslararası Turizm Hareketlerinde Sağlık Turizminin Rolü ve Kalite Çalışmalarının Önemi Bir Literatür Çalışması. Kahramanmaraş Sütçü İmam Üniversitesi İktisadi Ve İdari Bilimler Fakültesi Dergisi, 1(2), 135-156.

Peilt, E. (2009). Turizm İşletmelerinde Bilgi Teknolojileri Kullanımı Ve Yayg̨ınlaştırılmasına Yönelik Uygulamalar. Avrupa Birliği Eğitim ve Gençlik Programları Merkezi Başkanlığı Leonardo Da Vinci Hareketlilik Projesi, Proje No: 2008-1-TR-LEO02-01636, 14-16.

Turunç, Ö. (2006). Bilgi Teknolojileri Kullanımının İşletmelerin Örgütsel Performansına Etkisi hizmet Sektöründe Bir Araştırma. Süleyman Demirel Üniversitesi, Sosyal Bilimler Enstitüsü, İşletme Anabilim Dalı, Yayınlanmamış Doktora Tezi.

Ülker, E. (2010). Destinasyon Pazarlamasında Destinasyon Seçimi Karar Verme Süreci Üzerine Bir Çalışma. Trakya Üniversitesi, Sosyal Bilimler Enstitüsü, İşletme Anabilim Dalı, Yayınlanmamış Yüksek Lisans Tezi.

Uzun, Y., Arıkan, H., \& Tezel, G. (2016). Rule Extraction from Training Artificial Neural Network Using Variable Neighbourhood Search for Wisconsin Breast Cancer. Journal of Multidisciplinary Engineering Science and Technology (JMEST), 3(8), 5452-5458.

Yaraşlı, G. Y. (2007). Destinasyon İmajı ve Trabzon Yöresine Dönük Bir Çalışma. Başkent Üniversitesi, Sosyal Bilimler Enstitüsü, İşletme Ana Bilim Dalı, Yayınlanmamış Yüksek Lisans Tezi. 